\title{
Synthesis of $(S)-(+)-2-(N$-benzylamino)butan-1-ol from its Schiff Base by Catalytic Hydrogenation over Palladium
}

\author{
László Hegedüs $^{\mathrm{a}, *}$, Sándor Miskolczi ${ }^{\mathrm{b}}$, György Bánsághi ${ }^{\mathrm{c}}$, Edit Székely ${ }^{\mathrm{c}}$ and Ferenc Faigla ${ }^{\mathrm{a}, \mathrm{b}}$
}

${ }^{a}$ MTA-BME Organic Chemical Technology Research Group, Hungarian Academy of Sciences, Department of Organic Chemistry and Technology, Budapest University of Technology and Economics, Budafoki út 8, H-1111 Budapest, Hungary; ${ }^{b}$ Department of Organic Chemistry and Technology, Budapest University of Technology and Economics, Budafoki út 8, H-1111 Budapest, Hungary; ${ }^{\circ}$ Department of Chemical and Environmental Process Engineering, Budapest University of Technology and Economics, Budafoki út 8, H-1111 Budapest, Hungary

\begin{abstract}
A chiral 1,2-amino alcohol derivative, $(S)-(+)-2-(N$-benzylamino)butan-1-ol (BAB), was synthesized from its Schiff base by catalytic hydrogenation over palladium on carbon, in various solvents (toluene, methanol, hexane, dichloromethane, tetrahydrofuran, ethyl acetate), under mild conditions (room temperature, atmospheric pressure). Preparation of the Schiff base was also optimized. This compound is a resolving agent for preparing optically active, practically important cyclopropanecarboxylic acids.
\end{abstract}

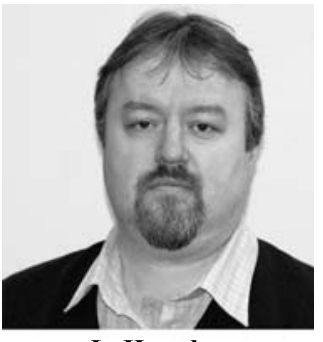

Keywords: Heterogeneous catalysis, hydrogenation, palladium, supported metal catalyst.

\section{INTRODUCTION}

Chiral 1,2-amino alcohols are common structural patterns found in a wide range of natural and biologically active molecules [1]. These compounds are useful precursors of various chiral oxazolidinones [2], oxazolines [3] or phosphonamides [4], and they are applied as catalyst ligands or chiral auxiliaries in relevant stereoselective reactions, such as hydrogenation of carbonyl compounds [5,6] or alkylation of enolates $[7,8]$, respectively. Furthermore, they can also be used as resolving agents [9].

In this work the liquid-phase heterogeneous catalytic hydrogenation of a Schiff base, $(S)-(+)-2-(N$-benzylidineamino)butan-1-ol (BDAB), to $(S)-(+)-2-(N$-benzylamino)butan-1-ol (BAB) over palladium was investigated in detail. BAB proved to be an efficient resolving agent in the optical resolution of practically important cyclopropanecarboxylic acids, such as cis- and trans-permethric acid (cis- and trans3-(2',2'-dichlorovinyl)-2,2-dimethylcyclopropanecarboxylic acid), based on diastereomeric salt formation using traditional methods [10-12] or new ones in supercritical carbon dioxide $[13,14]$.

Few examples have been reported on the heterogeneous catalytic hydrogenation of BDAB and its antipode [15-18], or other optically active Schiff bases prepared from $(R)-(-)-2-$ aminobutan-1-ol [19]. Thus, 2-( $N$-benzylidineamino)butan-1-ol was converted to 2 -( $N$-benzylamino)butan-1-ol with $68 \%$ yield, over $5 \% \mathrm{Pd} / \mathrm{C}$ (catalyst/substrate ratio $=0.1$ ), in ethanol, under 3.5 bar hydrogen pressure and at room temperature [15]. Similarly, $(R)-(-)-2-(N$-benzylidineamino)-

\footnotetext{
*Address correspondence to this author at the MTA-BME Organic Chemical Technology Research Group, Hungarian Academy of Sciences, Department of Organic Chemistry and Technology, Budapest University of Technology and Economics, Budafoki út 8, H-1111 Budapest, Hungary; Tel/Fax: (+36-1) 4631261; E-mail: lhegedus@mail.bme.hu
}

butan-1-ol was hydrogenated to $(R)-(-)-2-(N$-benzylamino $)-$ butan-1-ol with $77 \%$ yield, over $5 \%$ palladium on carbon (3\% by weight of substrate), in ethyl acetate, under 1 bar hydrogen pressure, at room temperature [16], while in isopropyl alcohol, applying 0.02 catalyst/substrate ratio, $89 \%$ yield was obtained at $70{ }^{\circ} \mathrm{C}$ for $24 \mathrm{hrs}$ [17]. Using a directreductive-amination (DRA) method [18], the hydrogenation of 2-( $N$-benzylidineamino)butan-1-ol with $10 \% \mathrm{Pd} / \mathrm{C}$, in methanol, in the presence of $\mathrm{CHCl}_{3}(6 \mathrm{v} / \mathrm{v} \%)$, at room temperature and atmospheric pressure resulted in $97 \%$ yield of 2-(N-benzylamino)butan-1-ol hydrochloride, namely hydrogen chloride was formed from chloroform due to the hydrodehalogenating ability of palladium. This process, however, has a disadvantage: it uses a non-environmentally benign, chlorinated additive $\left(\mathrm{CHCl}_{3}\right)$.

Further reduction methods were also applied for the saturation of $\mathrm{C}=\mathrm{N}$ bond of the Schiff base using sodium borohydride [20-24] or sodium cyanoborohydride [25] as reducing agents. For example, BDAB was reduced to BAB with $\mathrm{NaBH}_{4}$, in methanol, at $0{ }^{\circ} \mathrm{C}$ with $92 \%$ yield [21], while in ethanol $88 \%$ yield was obtained [22]. Whereas, it is inexpedient to apply sodium borohydride or cyanoborohydride, because they are harmful and expensive reagents, moreover the atom efficiency of this process $(72 \%)$ is worse than that of the catalytic hydrogenation (100\%). In addition, a large amount of hazardous waste is formed during the working-up procedure of the reaction mixture, which requires further destroying treatments.

Direct benzylation of $(S)-(+)$ or $(R)-(-)$-2-aminobutan-1-ol with benzyl bromide [26-29] or benzyl chloride [30] could be an alternative route for preparing the target compound. Thus, $(R)-(-)-2-(N$-benzylamino)butan-1-ol was prepared from $(R)$-(-)-2-aminobutan-1-ol using benzyl bromide, in boiling toluene, in the presence of $\mathrm{Na}_{2} \mathrm{CO}_{3}$ with $87 \%$ yield 
[26], while that of benzyl chloride the product was isolated with $94 \%$ yield [30]. However, due to the formation of $\mathrm{HBr}$ or $\mathrm{HCl}$ which have to be neutralized by sodium carbonate, a large amount of by-products can be formed increasing the environmental load.

An interesting electrocatalytic method was also used for the synthesis of $(R)-(-)-2-(N$-benzylamino)butan-1-ol [31]. Benzylamine was reacted with $(R)-(-)-2$-aminobutan-1-ol in methanol, in the presence of electrogenerated $O$ iminoquinone amine oxidase, at a $\mathrm{Pt}$ anode/ $\mathrm{Hg}$ cathode couple to give the product with $70 \%$ yield. Obviously, the use of mercury is the main disadvantage of this process from both practical and environmental points of view.

In this paper the preparation of the Schiff base, the effects of its purity, catalyst/substrate ratio, solvents on the selectivity to $\mathbf{B A B}$, as well as on the conversion and the rate of the hydrogenation of BDAB are discussed.

\section{RESULTS AND DISCUSSION}

\subsection{Preparation of the Schiff Base}

As well known [32,33], the formation of a Schiff base is a reversible reaction, but the equilibrium can be shifted toward the product by removing water from the reaction mixture. In our case, the Schiff base $[(S)-(+)-2-(N-$ benzylideneamino)butan-1-ol (BDAB)] was synthesized from $(S)-(+)$-2-aminobutan-1-ol (AB), an important intermediate of the antimycobacterial Ethambutol [34], and benzaldehyde (BA) (Scheme 1).

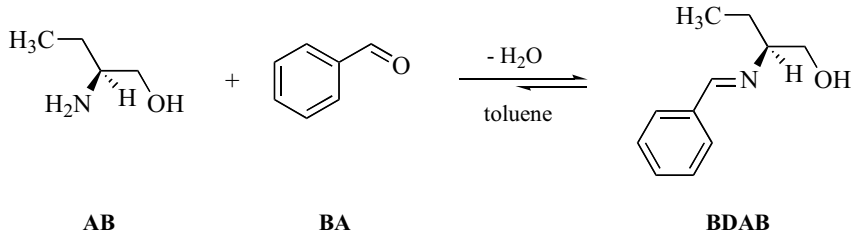

(Scheme 1). Formation of the Schiff base (BDAB) from $(S)-(+)-2-$ aminobutan-1-ol (AB) and benzaldehyde (BA).

The effect of reaction conditions used in the preparation of BDAB on the isolated yield and purity of the product is summarized in (Table 1).

Table 1. Preparation of the Schiff base (BDAB) under different conditions.

\begin{tabular}{|c|c|c|c|c|}
\hline Entry & Solvent & $\begin{array}{c}\text { Temperature } \\
\left({ }^{\circ} \mathbf{C}\right)\end{array}$ & $\begin{array}{c}\text { Isolated } \\
\text { Yield (\%) }\end{array}$ & $\begin{array}{c}\text { BDAB Content } \\
\mathbf{( \% )}\end{array}$ \\
\hline \hline 1 & methanol & 25 & 94 & 96.1 \\
\hline 2 & toluene & 25 & 86 & 94.4 \\
\hline 3 & toluene & 50 & 96 & 98.2 \\
\hline
\end{tabular}

Conditions: $0.89 \mathrm{~g}(10 \mathrm{mmol})(S)-(+)-2$-aminobutan-1-ol, $1.06 \mathrm{~g}(10 \mathrm{mmol})$ benzaldehyde, $35 \mathrm{~cm}^{3}$ solvent, reaction time: $10 \mathrm{~min}$.

As seen, the highest isolated yield (96\%) and purity $(98.2 \%)$ of BDAB were obtained in toluene and at $50{ }^{\circ} \mathrm{C}$, after $10 \mathrm{~min}$ reaction time (Table $\mathbf{1} /$ Entry 3 ). Without heating, at $25{ }^{\circ} \mathrm{C}$, the starting materials were not able to dissolve completely into toluene, therefore the isolated yield decreased significantly $(96 \rightarrow 86 \%)$ and the BDAB content became lower $(98.2 \rightarrow 94.4 \%)$ (Table 1/Entry 2$)$. In methanol and at room temperature, both the isolated yield (94\%) and the purity $(96.1 \%)$ values were slightly worse than in toluene (Table 1/Entry 1), despite the good solubility of the reactants. It is noteworthy, that evaporation of the organic solvents used, under vacuum, was carried out at $50{ }^{\circ} \mathrm{C}$ and for $30 \mathrm{~min}$ to remove the traces of water, as well.

According to our results, it is expedient to carry out this reaction in toluene and at $50{ }^{\circ} \mathrm{C}$ to achieve the highest isolated yield and purity of $(S)-(+)-2-(N$-benzylideneamino $)$ butan1 -ol. Furthermore, it is favourable to apply a slight excess of benzaldehyde $(\sim 1 \%)$ during the preparation of this Schiff base, because the optically active $(S)-(+)$-2-aminobutan-1-ol itself could also act as a resolving agent and it could modify the efficiency of the final product in a resolving process.

\subsection{Hydrogenation of the Schiff Base}

\subsubsection{Reaction Pathway}

The possible reaction pathways, intermediates and products in the hydrogenation of the Schiff base (BDAB) are shown in (Scheme 2). Formation of $(S)-(+)-2-(N-$ benzylamino)butan-1-ol (BAB) takes place by hydrogenation of BDAB, but a tertiary amine derivative, $(S)-(+)-2-(N, N-$ dibenzylamino)butan-1-ol (DBAB), can be formed in a coupling reaction of $\mathbf{B A B}$ and the excess of benzaldehyde (BA) accompanied by elimination of water and followed by hydrogenation. Toluene (T) and BAB can also be formed in a hydrogenolytic step from DBAB. Furthermore, BA can be hydrogenated to benzyl alcohol (BnOH) which also undergoes hydrogenolysis to give toluene.

In methanol, however, a further side-reaction can take place, because the debenzylation of BAB can result in $(S)$ $(+)$-2-aminobutan-1-ol (AB) and toluene, but this hydrogenolysis usually takes place under pressure.

\subsubsection{Effect of Purity of the Schiff Base}

The results of the hydrogenation of BDAB prepared in different ways, over $10 \% \mathrm{Pd} / \mathrm{C}$ catalyst (Selcat $\mathrm{Q}$ ) are given in (Table 2).

Although in methanol, without preparing the Schiff base, the complete reduction of BDAB took place fast, both the purity of product $(92.0 \%$ BAB content) and the selectivity to BAB $(82 \%)$ became significantly lower than in toluene $(98.9$ and $84 \%$, respectively), while similar isolated yields were obtained (85-89\%) (Table 2/Entries 1 and 4). In case of prepared Schiff base, in methanol again, the reaction also started very fast, as seen in (Fig. 1), whereas the rate of the hydrogen uptake decreased after $10 \mathrm{~min}$. Moreover, the purity of product, the isolated yield and the selectivity values further diminished $(92.0 \rightarrow 88.3 \%, \quad 89 \rightarrow 85 \%$, as well as $82 \rightarrow 75 \%$ ) (Table 2/Entry 2). According to the GC-MS measurements, this was due to $(S)-(+)$-2-aminobutan-1-ol formed in a higher amount (6-8\%), namely the $N$ debenzylation of $\mathbf{B A B}$ took place partly in methanol, even at atmospheric pressure and room temperature, but that of secondary amines, in general, requires higher pressure ( $>4$ bar) and temperature $\left(>40{ }^{\circ} \mathrm{C}\right)$ [35]. Applying toluene the purity of product, irrespectively of the preparation method of the 


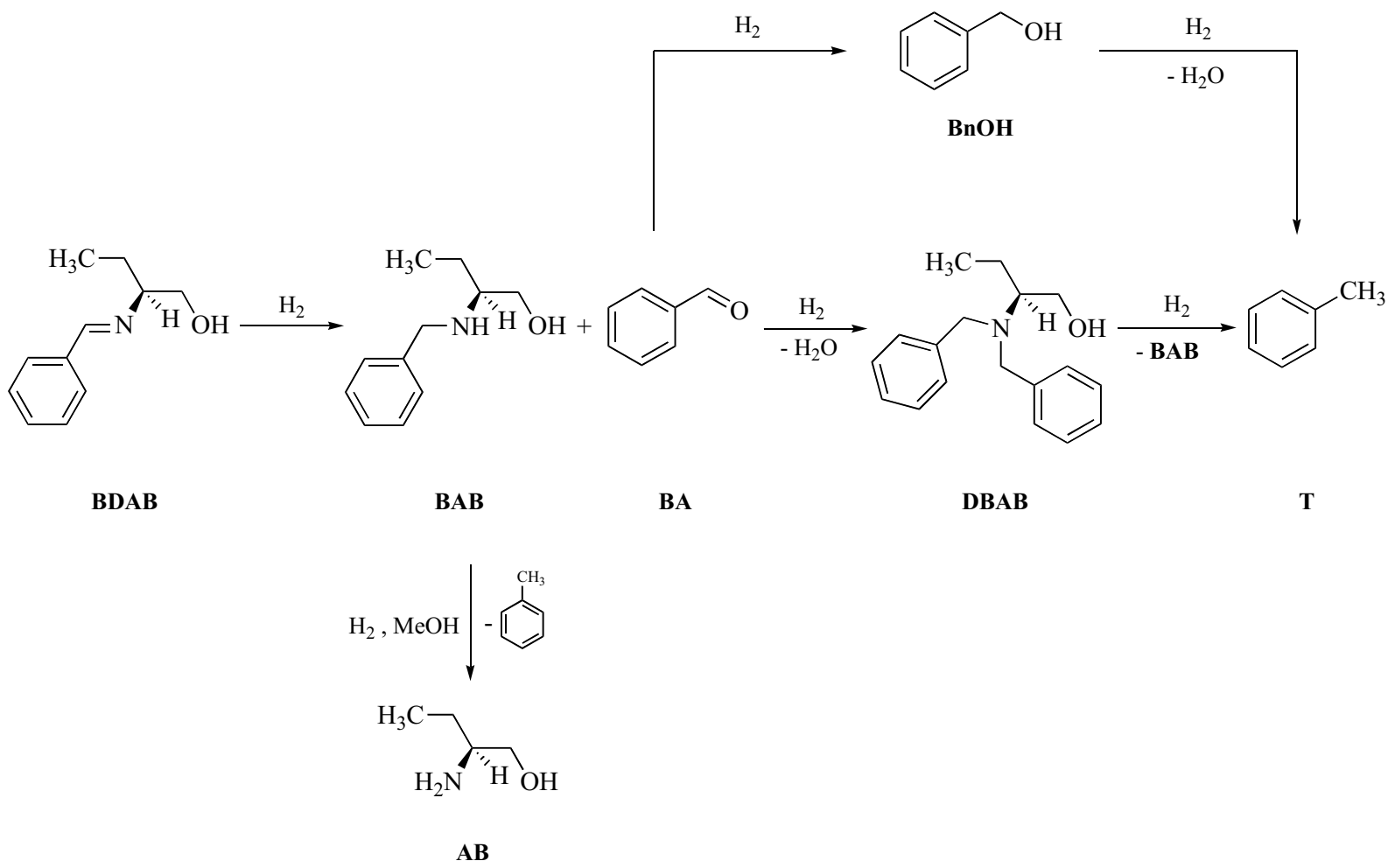

(Scheme 2). Reaction pathways in the hydrogenation of $(S)-(+)-2-(N$-benzylideneamino)butan-1-ol (BDAB).

Table 2. Hydrogenation of the Schiff base (BDAB) prepared in different ways.

\begin{tabular}{|c|c|c|c|c|c|c|}
\hline Entry & Solvent & $\begin{array}{l}\text { Reaction Time for Complete } \\
\text { Conversion (min) }\end{array}$ & Isolated Yield (\%) & BAB Content (\%) & Selectivity (\%) & $\begin{array}{c}v_{0} \\
\left(\mathbf{m m o l ~ H}_{2} \operatorname{mmol}_{\mathrm{Pd}}{ }^{-1} \min ^{-1}\right)\end{array}$ \\
\hline $1^{\mathrm{a}}$ & methanol & 17 & 89 & 92.0 & 82 & 2.35 \\
\hline $2^{\mathrm{b}}$ & methanol & 30 & 85 & 88.3 & 75 & 3.17 \\
\hline $3^{\mathrm{c}}$ & toluene & 25 & 84 & 97.8 & 82 & 1.66 \\
\hline $4^{\mathrm{d}}$ & toluene & 30 & 85 & 98.9 & 84 & 1.91 \\
\hline
\end{tabular}

Conditions: $1.70 \mathrm{~g}$ Schiff base, $0.34 \mathrm{~g} 10 \% \mathrm{Pd} / \mathrm{C}$ catalyst (Selcat Q), $30 \mathrm{~cm}^{3}$ solvent, atmospheric pressure, $25^{\circ} \mathrm{C}$.

${ }^{\text {a }}$ Schiff base was not prepared.

${ }^{\mathrm{b}}$ Schiff base was prepared.

${ }^{\mathrm{c}}$ Schiff base was prepared at $25^{\circ} \mathrm{C}$.

${ }^{\mathrm{d}}$ Schiff base was prepared at $50^{\circ} \mathrm{C}$.

Schiff base, was very high ( 97.8 and $98.9 \%$ BAB content, respectively), while the isolated yields were almost the same $(84-85 \%)$ which resulted in high selectivities to $\mathbf{B A B}(82-$ 84\%) (Table 2/Entries 3 and 4).

It can also be observed that the initial rates $\left(v_{0}\right)$ were higher in methanol $\left(2.35\right.$ and $3.17 \mathrm{mmol} \mathrm{H}_{2}$ mmol $\left._{\text {Pd }^{-1}} \min ^{-1}\right)$ than in toluene (1.66 and $1.91 \mathrm{mmol} \mathrm{H}_{2} \mathrm{mmol}_{\mathrm{Pd}}{ }^{-1} \mathrm{~min}^{-1}$ ), due to the different polarities of these solvents.

These results confirm our findings described in Section 2.1., i.e. it is favourable to synthesize the Schiff base in warm toluene $\left(50{ }^{\circ} \mathrm{C}\right)$ and to isolate it. On the other hand, it is inexpedient to carry out its hydrogenation in methanol (a protic solvent) due to the considerable hydrogenolytic sidereactions.

\subsubsection{Influence of Amount of Catalyst}

The influence of different amount of $10 \% \mathrm{Pd} / \mathrm{C}$ (Selcat Q) catalyst on the hydrogenation of BDAB, in toluene, is shown in (Table 3).

As seen, increasing the catalyst/substrate ratio $(0.02 \rightarrow 0.3)$ was accompanied with decreasing the isolated yield of BAB $(93 \rightarrow 83 \%)$. Presumably, due to the large adsorption capacity of activated carbon, a small portion of the product, which was directly proportional to the amount of catalyst, remained on the surface of it. In all cases, however, the conversion of BDAB was complete, but this required longer reaction time $(85 \mathrm{~min})$ using a lower quantity of catalyst $\left(0.02 \mathrm{gg}^{-1}\right)$ than at 0.3 catalyst/substrate ratio $(20$ min) (Table 3/Entries 1 and 5). The purity of product, irre- 
spectively of the amount of catalyst, was very high $(>96 \%$ BAB content) in every hydrogenation reaction.

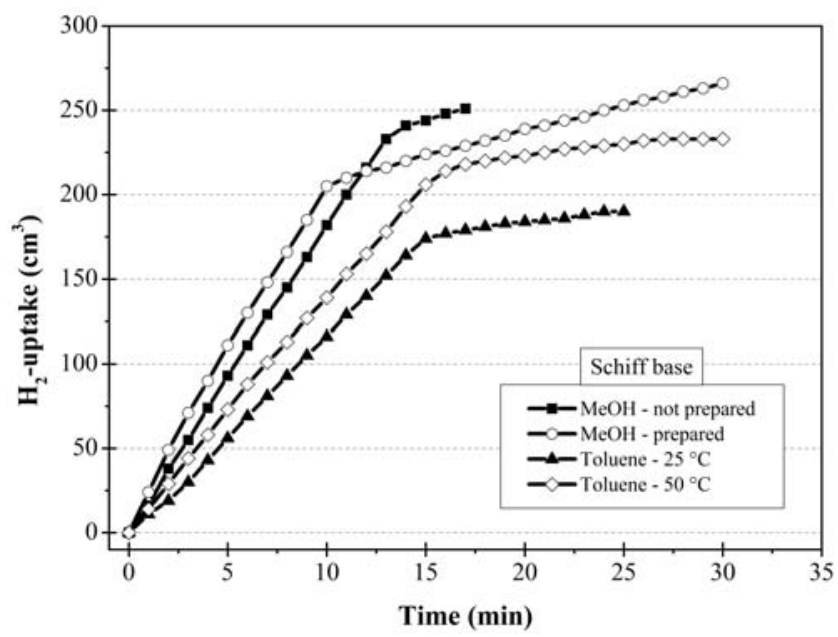

Fig. (1). Hydrogen uptake of BDAB prepared in different ways $v s$. time. Conditions: see Table 2.

Furthermore, the initial rates gradually diminished $\left(4.47 \rightarrow 1.60 \mathrm{mmol} \mathrm{H}_{2} \mathrm{mmol}_{\mathrm{Pd}}{ }^{-1} \mathrm{~min}^{-1}\right.$ ) by increasing the catalyst/substrate ratio which refers to mass transport limitation. This phenomenon often occurs in atmospheric hydrogenations, especially in case of functional groups (e.g. $\mathrm{NO}_{2}$, $\mathrm{C}=\mathrm{C}, \mathrm{C}=\mathrm{N}$ ) to be hydrogenated easily.

On the basis of our results, it can be stated that applying 0.02 catalyst/substrate ratio is enough to obtain $(S)-(+)-2-(N-$ benzylamino)butan-1-ol with complete conversion, high purity $(\sim 97 \%$ BAB content), isolated yield (93\%) and selectivity $(90 \%)$, in toluene.

\subsubsection{Effect of Solvents}

As known [36], in the catalytic hydrogenations both the selectivity of a reaction and the activity of a catalyst can be influenced by using appropriate solvents.

The results of the hydrogenation of BDAB in different solvents, over 10\% $\mathrm{Pd} / \mathrm{C}$ (Selcat $\mathrm{Q}$ ) catalyst are summarized in (Table 4).

In dichloromethane or ethyl acetate BAB was obtained with purity below $94 \%$ which is not suitable for optical resolution (Table 4/Entries 2 and 5). In addition, as seen in (Fig.
$2)$, the reaction was the slowest in dichloromethane $\left(v_{0}=1.52\right.$ $\mathrm{mmol} \mathrm{H}_{2} \mathrm{mmol}_{\mathrm{Pd}}{ }^{-1} \mathrm{~min}^{-1}$ ), but the isolated yield (95\%) was the highest among solvents tested (Table 4/Entry 2). In these reductions the ratio of the "favourable" hydrogenolytic steps shown in (Scheme 2) decreased resulting in more byproduct, namely benzyl alcohol was formed in a higher amount (4-5\%) and remained in the isolated product, i.e. its further hydrogenolysis to toluene was avoided. Since the application of dichloromethane is limited due to its harmful properties, it can be replaced by ethyl acetate without significant decreasing in activity and selectivity. Using toluene or tetrahydrofuran the product was formed with adequate purity $(>95 \%)$, and the initial rates $\left(v_{0}\right)$ were high $(3.04$ and 2.56 $\mathrm{mmol} \mathrm{H}_{2} \mathrm{mmol}_{\mathrm{Pd}}{ }^{-1} \mathrm{~min}^{-1}$ ) (Table 4/Entries 1 and 3).

In hexane, after reaching about $80 \%$ conversion of BDAB, the product was precipitated from the reaction mixture. Surprisingly, despite this agglomeration of $\mathbf{B A B}$, the reduction took place with practically complete conversion (Table 4/Entry 4). After filtering the catalyst-product suspension, the precipitated $\mathbf{B A B}$ was dissolved in toluene and the solvent was evaporated in vacuum which resulted in extremely pure $(S)-(+)-2-(N$-benzylamino)butan-1-ol $(99.5 \%)$. Although the isolated yield became significantly lower $(72 \%)$ than its average value $(90 \%)$, this loss corresponds with the two crystallization of the crude product.

This "recrystallizing" hydrogenation method, however, may provide new facilities for the liquid-phase, heterogeneous catalytic hydrogenations. Using this technique, the amount of solvents applied can be reduced, and thus the environmental load can be decreased, as well as the apparatus demand can be lower and the operation time can be shorter.

\subsection{5. “Recrystallizing” Hydrogenations}

The results of the "recrystallizing" hydrogenation of BDAB in hexane, over $10 \% \mathrm{Pd} / \mathrm{C}$ (Selcat Q) catalyst are shown in (Table 5).

At lower catalyst/substrate ratios $(0.05$ and 0.08$)$ the catalyst was agglomerated by the substrate and this conglomerate separated out onto the wall of reactor, thus the rate of hydrogen uptake was very low. Therefore dichloromethane or toluene were added to the reaction mixture, wich resulted in change of consistency of the reaction mixture, to make easier the course of hydrogenation (Table 5/Entries 1 and 2). However, the aforementioned product precipitation was observed only at $0.08-0.3$ catalyst/substrate ratios, which was accom-

Table 3. Influence of amount of catalyst $(10 \% \mathrm{Pd} / \mathrm{C})$ in the hydrogenation of BDAB.

\begin{tabular}{|c|c|c|c|c|c|c|}
\hline Entry & $\begin{array}{l}\text { Catalyst/substrate } \\
\text { Ratio }\left(\mathrm{g} \mathrm{g}^{-1}\right)\end{array}$ & $\begin{array}{l}\text { Reaction Time for Complete } \\
\text { Conversion (min) }\end{array}$ & $\begin{array}{c}\text { Isolated Yield } \\
(\%)\end{array}$ & $\begin{array}{c}\text { BAB Content } \\
(\%)\end{array}$ & $\begin{array}{l}\text { Selectivity } \\
(\%)\end{array}$ & $\begin{array}{c}v_{0} \\
\left(\mathrm{mmol} \mathrm{H}_{2} \mathbf{m m o l}_{\mathrm{Pd}}{ }^{-1} \min ^{-1}\right)\end{array}$ \\
\hline 1 & 0.02 & 85 & 93 & 96.9 & 90 & 4.47 \\
\hline 2 & 0.05 & 40 & 91 & 96.6 & 88 & 3.56 \\
\hline 3 & 0.1 & 40 & 88 & 96.9 & 86 & 3.04 \\
\hline 4 & 0.2 & 30 & 85 & 98.9 & 84 & 1.91 \\
\hline 5 & 0.3 & 20 & 83 & 96.4 & 80 & 1.60 \\
\hline
\end{tabular}

Conditions: $1.70 \mathrm{~g}$ Schiff base, $10 \% \mathrm{Pd} / \mathrm{C}$ catalyst (Selcat $\mathrm{Q}), 30 \mathrm{~cm}^{3}$ toluene, atmospheric pressure, $25^{\circ} \mathrm{C}$. 
Table 4. Effect of solvents in the hydrogenation of BDAB.

\begin{tabular}{|c|c|c|c|c|c|c|}
\hline Entry & Solvent & Conversion (\%) & $\begin{array}{c}\text { Isolated Yield } \\
(\%)\end{array}$ & $\begin{array}{c}\text { BAB Content } \\
(\%)\end{array}$ & $\begin{array}{c}\text { Selectivity } \\
(\%)\end{array}$ & $\frac{v_{0}}{\left(\mathrm{mmol} \mathrm{H}_{2} \mathrm{mmol}_{\mathrm{Pd}}^{-1} \min ^{-1}\right)}$ \\
\hline 1 & toluene & 100 & 88 & 96.9 & 86 & 3.04 \\
\hline 2 & dichloromethane & 98 & 95 & 92.8 & 90 & 1.52 \\
\hline 3 & tetrahydrofuran & 98 & 91 & 95.4 & 82 & 2.56 \\
\hline $4^{\mathrm{a}}$ & hexane & 98 & $72^{b}$ & $99.5^{b}$ & $73^{b}$ & 2.04 \\
\hline $5^{\mathrm{c}}$ & ethyl acetate & 98 & 94 & 93.7 & 90 & 3.13 \\
\hline
\end{tabular}

Conditions: $1.70 \mathrm{~g}$ Schiff base, $0.17 \mathrm{~g} 10 \% \mathrm{Pd} / \mathrm{C}$ catalyst (Selcat Q), $30 \mathrm{~cm}^{3}$ solvent, atmospheric pressure, $25^{\circ} \mathrm{C}$, reaction time: $40 \mathrm{~min}$.

${ }^{\text {a }}$ Product precipitation.

${ }^{\mathrm{b}}$ These values are referred to the precipitated product dissolved by toluene.

${ }^{\mathrm{c}}$ Reaction time: $30 \mathrm{~min}$

panied with decreasing the isolated yield of $\mathbf{B A B}$ $(94 \rightarrow 72 \%$ ) (Table 5/Entries 2-4). In all cases the conversion of BDAB was pratically complete, but this required longer reaction time $(75 \mathrm{~min})$ using a lower quantity of catalyst $\left(0.05 \mathrm{gg}^{-1}\right)$ than at 0.3 catalyst/substrate ratio $(30 \mathrm{~min})$ (Table 5/Entries 1 and 4). Furthermore, similarly to toluene (Section 2.2.3.), the purity of product, irrespectively of the amount of catalyst, was also very high ( $>98 \%$ BAB content).

Accordingly, in hexane it is favourable to use 0.1 catalyst/substrate ratio of $10 \% \mathrm{Pd} / \mathrm{C}$ to achieve excellent purity of the product $(99.5 \%)$, near complete conversion and reasonable isolated yield $(72 \%)$ during the preparation of $(S)$ (+)-2-( $N$-benzylamino)butan-1-ol.

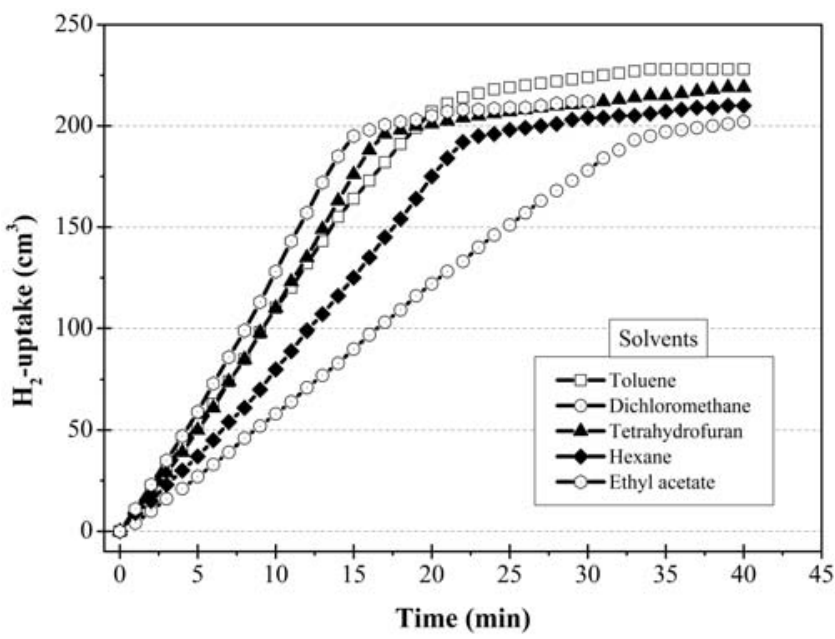

Fig. (2). Hydrogen uptake of BDAB vs. time in different organic solvents. Conditions: see Table 4.

\section{CONCLUSIONS}

An efficient and environmentally benign method for the synthesis of $(S)-(+)-2-(N$-benzylamino)butan-1-ol (BAB) from its Schiff base by palladium mediated, heterogeneous catalytic hydrogenation was developed. We found that it is favourable to synthesize the Schiff base in warm toluene $\left(50{ }^{\circ} \mathrm{C}\right)$ to achieve the highest isolated yield (96\%) and purity $(98.2 \%)$ of $(S)-(+)-2-(N$-benzylideneamino $)$ butan-1-ol, as well as it is expedient to carry out its catalytic hydrogenation in an apolar solvent (toluene) to obtain $(S)-(+)-2-(N-$ benzylamino)butan-1-ol with high purity $(>95 \%)$ and complete conversion, in a fast reaction.

Applying $10 \% \quad \mathrm{Pd} / \mathrm{C}$ (Selcat Q) catalyst, at 0.02 catalyst/substrate ratio, in toulene, at room temperature and atmospheric pressure BAB was isolated with high purity $(97 \%)$, isolated yield (93\%) and selectivity (90\%). In this form it can be used as a resolving agent.

Although product precipitation was observed during the hydrogenations carried out in hexane, the reduction took place with neat complete conversion and resulted in extremely pure $(S)-(+)-2-(N$-benzylamino)butan-1-ol $(99.5 \%)$, but with lower isolated yield $(72 \%)$. This "recrystallizing" hydrogenation method, however, may provide new facilities for the liquid-phase, heterogeneous catalytic hydrogenations (lower solvent, apparatus or time demand).

\section{EXPERIMENTAL}

\subsection{Materials}

The $10 \% \mathrm{Pd} / \mathrm{C}$ (Selcat $\mathrm{Q}$ ) catalyst was manufactured in accordance with the patent [37], in the Szilor Fine Chemicals (Budapest, Hungary). The dispersion of the catalyst, determined by $\mathrm{H}_{2-}, \mathrm{O}_{2^{-}}$and $\mathrm{CO}$-chemisorption measurements, is the following: $D_{10 \% \mathrm{Pd} / \mathrm{C}}=0.50$ [38].

Benzaldehyde $(>99 \%)$ and $(S)-(+)$-2-aminobutan-1-ol $(>98 \%)$ were supplied by Sigma-Aldrich (Steinheim, Germany), while toluene (p.a.), methanol (p.a.), dichloromethane (p.a.), tetrahydrofuran (p.a.), ethyl acetate (p.a.) and hexane (p.a.) were purchased from Merck-Schuchardt (Dramstadt, Germany).

\subsection{Preparation of the Schiff Base}

To a solution of $(S)-(+)$-2-aminobutan-1-ol (AB) $(0.89 \mathrm{~g}$, $10 \mathrm{mmol})$ in toluene $\left(20 \mathrm{~cm}^{3}\right)$ was added benzaldehyde (BA) $(1.06 \mathrm{~g}, 10 \mathrm{mmol})$ in toluene $\left(10 \mathrm{~cm}^{3}\right)$. The mixture was stirred at $50{ }^{\circ} \mathrm{C}$ for $10 \mathrm{~min}$. After cooling it was evaporated under vacuum (30 $\mathrm{min})$ to obtain $1.70 \mathrm{~g}(9.6 \mathrm{mmol})$ crude product $[(S)-(+)-2-(N$-benzylideneamino $)$ butan-1-ol, BDAB $]$ with $96 \%$ yield, as a yellowish oil. ${ }^{1} \mathrm{H}$ NMR $\left(\mathrm{CDCl}_{3}, 300\right.$ $\mathrm{MHz}) \delta 0.86\left(\mathrm{t}, J=7.4 \mathrm{~Hz}, 3 \mathrm{H}, \mathrm{CH}_{2} \mathrm{CH}_{3}\right), 1.53-1.67(\mathrm{~m}, 2 \mathrm{H}$, 
Table 5. "Recrystallizing” hydrogenation of BDAB in hexane.

\begin{tabular}{|c|c|c|c|c|c|c|c|}
\hline Entry & $\begin{array}{c}\text { Catalyst/substrate } \\
\text { Ratio }\left(\mathrm{g} \mathrm{g}^{-1}\right)\end{array}$ & $\begin{array}{l}\text { Reaction Time } \\
\text { (min) }\end{array}$ & $\begin{array}{c}\text { Conversion } \\
(\%)\end{array}$ & $\begin{array}{c}\text { Isolated Yield } \\
(\%)\end{array}$ & $\begin{array}{c}\text { BAB Content } \\
(\%)\end{array}$ & $\begin{array}{l}\text { Selectivity } \\
(\%)\end{array}$ & $\begin{array}{c}v_{0} \\
\left(\mathbf{m m o l ~ H}_{2} \operatorname{mmol}_{\mathbf{P d}}{ }^{-1} \min ^{-1}\right)\end{array}$ \\
\hline $1^{\mathrm{a}}$ & 0.05 & 75 & 98 & 94 & 96.4 & 90 & 0.87 \\
\hline $2^{\mathrm{b}, \mathrm{d}}$ & 0.08 & 70 & 98 & $61^{\mathrm{c}}$ & $98.8^{\mathrm{c}}$ & $62^{c}$ & 1.04 \\
\hline $3^{b}$ & 0.1 & 40 & 98 & $72^{\mathrm{c}}$ & $99.5^{\mathrm{c}}$ & $73^{\mathrm{c}}$ & 2.04 \\
\hline $4^{b}$ & 0.3 & 30 & 99 & $69^{c}$ & $98.6^{c}$ & $69^{c}$ & 1.60 \\
\hline
\end{tabular}

Conditions: $1.70 \mathrm{~g}$ Schiff base, $10 \% \mathrm{Pd} / \mathrm{C}$ catalyst (Selcat Q), $30 \mathrm{~cm}^{3}$ hexane, atmospheric pressure, $25{ }^{\circ} \mathrm{C}$

${ }^{\text {a }}$ Dichloromethane was added $\left(+5 \mathrm{~cm}^{3}\right)$.

${ }^{\mathrm{b}}$ Product precipitation.

${ }^{\mathrm{c}}$ These values are referred to the precipitated product dissolved by toluene.

${ }^{\mathrm{d}}$ Toluene was added $\left(+5 \mathrm{~cm}^{3}\right)$.

$\mathrm{CH}_{2} \mathrm{CH}_{3}$ ), 2.93 (br s, 1H, OH), 3.15-3.23 (m, 1H, CH), 3.69-3.81 (m, 2H, $\left.\mathrm{CH}_{2} \mathrm{OH}\right), 7.32-7.40$ (m, 3H, Ar- H), 7.68$7.71(\mathrm{~m}, 2 \mathrm{H}, \mathrm{Ar}-H), 8.25(\mathrm{~s}, 1 \mathrm{H}, \mathrm{CH}=\mathrm{N}) ;{ }^{13} \mathrm{C} \mathrm{NMR}\left(\mathrm{CDCl}_{3}\right.$, $75 \mathrm{MHz}) \delta 10.74\left(\mathrm{CH}_{3}\right), 25.04\left(\mathrm{CH}_{2}\right), 66.10\left(\mathrm{CH}_{2} \mathrm{OH}\right), 74.60$ $(\mathrm{CH}), 128.36(2 \times \mathrm{Ar}-\mathrm{CH}), 128.60(2 \times \mathrm{Ar}-\mathrm{CH}), 130.79$ (Ar$\mathrm{CH}), 135.89$ (Ar-C), $162.05(\mathrm{CH}=\mathrm{N}) ; \mathrm{GC}-\mathrm{MS} m / z(\mathrm{rel} \%)$ 176(8), 146(100), 91(52), 77(15), 41(22), 28(21). Mass spectra (MS) of the starting materials detected by GC are the following: AB $\mathrm{m} / \mathrm{z}$ (rel\%) 89(1), 58(100), 42(43), 30(33); BA $m / z$ (rel\%) 106(46), 105(47), 77(100), 51(46), 28(58). These analytical results are in agreement with the literary data $[17,39]$.

\subsection{Hydrogenations}

The hydrogenation reactions were carried out in a conventional atmospheric pressure apparatus with a magnetic stirrer (stirring speed: $1100 \mathrm{rpm}$ ), at room temperature. The initial rates $\left(v_{0}\right)$ were determined from the hydrogen consumption curves.

Typically, the reactor containing BDAB (1.70 g), 10\% $\mathrm{Pd} / \mathrm{C}$ catalyst $(0.17 \mathrm{~g})$ and toluene $\left(30 \mathrm{~cm}^{3}\right)$ was flushed with nitrogen and hydrogen, then charged with hydrogen to the specified pressure. After finishing the hydrogen uptake, the catalyst was filtered off and the solvent was removed in vacuum. The amount of the pale yellow, solid, crude product was $1.62 \mathrm{~g}(91 \%)$. After recrystallisation from hexane $(S)$ (+)-2-( $N$-benzylamino)butan-1-ol (BAB) was obtained as a white solid. M.p. $71-72{ }^{\circ} \mathrm{C} ;{ }^{1} \mathrm{H}$ NMR $\left(\mathrm{CDCl}_{3}, 300 \mathrm{MHz}\right) \delta$ $0.93\left(\mathrm{t}, J=7.5 \mathrm{~Hz}, 3 \mathrm{H}, \mathrm{CH}_{2} \mathrm{CH}_{3}\right), 1.46-1.57(\mathrm{~m}, 2 \mathrm{H}$, $\mathrm{CH}_{2} \mathrm{CH}_{3}$ ), 1.89 (br s, 2H, $\mathrm{NH}$ and $\left.\mathrm{OH}\right), 2.62-2.66(\mathrm{~m}, 1 \mathrm{H}$, $\mathrm{CH}), 3.34(\mathrm{dd}, J=10.6,6.3 \mathrm{~Hz}, 1 \mathrm{H}, \mathrm{CH} \mathrm{HOH}), 3.66$ (dd, $J=10.6,3.8 \mathrm{~Hz}, 1 \mathrm{H}, \mathrm{CH} H \mathrm{OH}), 3.81$ (dd, $J=12.9,9.0 \mathrm{~Hz}, 2 \mathrm{H}$, $\left.\mathrm{PhCH}_{2}\right), 7.26-7.34(\mathrm{~m}, 5 \mathrm{H}, \mathrm{Ar}-\mathrm{H}) ;{ }^{13} \mathrm{C} \mathrm{NMR}\left(\mathrm{CDCl}_{3}, 75\right.$ $\mathrm{MHz}) \delta 10.58\left(\mathrm{CH}_{3}\right), 24.52\left(\mathrm{CH}_{2}\right), 51.21\left(\mathrm{PhCH}_{2}\right), 59.94$ $(\mathrm{CH}), 62.73\left(\mathrm{CH}_{2} \mathrm{OH}\right), 127.35(\mathrm{Ar}-\mathrm{CH}), 128.33(2 \times \mathrm{Ar}-\mathrm{CH})$, 128.72 (2×Ar-CH), 140.51 (Ar-C); GC-MS m/z (rel\%) 178(1), 148(30), 91(100), 70(12), 65(18); $[\alpha]_{D}^{20}=+23.3(c$ 0.9 , EtOH); lit. $[\alpha]_{D}^{20}=+28.0\left(c\right.$ 1.2, $\left.\mathrm{CHCl}_{3}\right)$ [22]. Mass spectra (MS) of the by-products formed in lower amounts and detected by $\mathrm{GC}$ are the following: $(S)-(+)-2-(N, N-$ dibenzylamino)butan-1-ol (DBAB) $m / z($ rel\%) 268(1), 238
(25), 190(8), 146(5), 91(100), 65(12); benzyl alcohol (BnOH) $m / z(r e l \%) ~ 108(40), 91(12), 79(100), 77(60), 51(21)$ 39(11). These analytical results are in agreement with the literary data [39].

Every hydrogenation was reproduced 2-3 times, and the average value of the results was given. The deviation was less than $5 \%$.

\subsection{Analysis}

The ${ }^{1} \mathrm{H}$ and ${ }^{13} \mathrm{C}$ NMR spectra were recorded on a Bruker AV-300 spectrometer operating at 300 and $75 \mathrm{MHz}$, respectively, in chloroform-D1 $\left(\mathrm{CDCl}_{3}\right)$. Chemical shifts are given relative to $\delta_{\mathrm{TMS}}$.

GC analyses were carried out with a Thermo Finnigan Focus GC apparatus using a Supelco $\beta$-DEX ${ }^{\mathrm{TM}} 120$ capillary column $(30 \mathrm{~m} \times 0.25 \mathrm{~mm}$ ID, $0.25 \mu \mathrm{m}$ film $)$ FID. The temperature program was the following: $90{ }^{\circ} \mathrm{C}(4 \mathrm{~min})$ to $210{ }^{\circ} \mathrm{C}$ at $10{ }^{\circ} \mathrm{C} / \mathrm{min}$ and hold $5 \mathrm{~min}$, then to $220^{\circ} \mathrm{C}$ at $10{ }^{\circ} \mathrm{C} / \mathrm{min}$, hold $5 \mathrm{~min}$.

GC-MS analyses were carried out with a Finnigan Mat/Automass II GC/MS spectrometer using a Zebron ZB$5 \mathrm{~ms}$ capillary column $(30 \mathrm{~m} \times 0.25 \mathrm{~mm} \mathrm{ID}, 0.25 \mu \mathrm{m}$ film $)$. The temperature program was the following: $45^{\circ} \mathrm{C}$ (2 min) to $300{ }^{\circ} \mathrm{C}$ at $10{ }^{\circ} \mathrm{C} / \mathrm{min}$, then to $350{ }^{\circ} \mathrm{C}$ at $25^{\circ} \mathrm{C} / \mathrm{min}$.

Melting points were taken using a MEL-TEMP ${ }^{\circledR}$ apparatus and are uncorrected. Optical rotations were measured with a Perkin-Elmer 241 automatic polarimeter.

Selectivity values to $\mathbf{B A B}$ were calculated according to the following equation:

$$
\text { Selectivity }(\%)=\frac{\text { isolated yield } \times \mathbf{B A B} \text { content }}{\text { conversion }} \times 100
$$

\section{CONFLICT OF INTEREST}

The authors confirm that this article content has no conflicts of interest.

\section{ACKNOWLEDGEMENTS}

This work was supported by the Hungarian Scientific Research Fund (OTKA K104528 and K108979). E. Székely thanks the Hungarian Academy of Sciences for a Bolyai János Research Scholarship. 


\section{REFERENCES}

[1] Ager, D.J.; Indra Prakash, I.; Schaad, D.R. 1,2-Amino alcohols and their heterocyclic derivatives as chiral auxiliaries in asymmetric synthesis. Chem. Rev., 1996, 96, 835-875.

[2] Casadei, M.A.; Feroci, M.; Inesi, A.; Rossi, L.; Sotgiu, G. The reaction of 1,2-amino alcohols with carbon dioxide in the presence of 2-pyrrolidone electrogenerated base. New synthesis of chiral oxazolidin-2-ones. J. Org. Chem., 2000, 65, 4759-4761.

[3] Meyers, A.I.; Knaus, G.; Kamata, K.; Ford, M.E. Asymmetric synthesis of $R$ and $S \alpha$-alkylalkanoic acids from metalation and alkylation of chiral 2-oxazolines. J. Am. Chem. Soc., 1976, 98, 567576.

[4] Hua, D.H.; Chan-Yu-King, R.; McKie, J.A.; Myer, L. Remarkable enantioselective 1,4-addition reactions of chiral allylphosphonyl anions (ambident nucleophiles) with cyclic enones (ambident electrophiles). J. Am. Chem. Soc., 1987, 109, 5026-5029.

[5] Noyori, R.; Hashiguchi, S. Asymmetric transfer hydrogenation catalyzed by chiral ruthenium complexes. Acc. Chem. Res., 1997, 30, 97-102.

[6] Palmer, M.; Walsgrove, T.; Wills, M. (1R,2S)-(+)-cis-1-Amino-2indanol: An effective ligand for asymmetric catalysis of transfer hydrogenations of ketones. J. Org. Chem., 1997, 62, 5226-5228.

[7] Myers, A.G.; Gleason, J.L.; Yoon, T. A practical method for the synthesis of D- or L- $\alpha$-amino acids by the alkylation of (+)- or (-)pseudoephedrine glycinamide. J. Am. Chem. Soc., 1995, 117, 84888489.

[8] Myers, A.G.; Yang, B.H.; Chen, H.; McKinstry, L.; Kopecky, D.J.; Gleason, J.L. Pseudoephedrine as a practical chiral auxiliary for the synthesis of highly enantiomerically enriched carboxylic acids, alcohols, aldehydes, and ketones. J. Am. Chem. Soc., 1997, 119, 6496-6511.

[9] Faigl, F.; E. Fogassy, E.; Nógrádi M.; Pálovics, E.; Schindler, J. Strategies in optical resolution: A practical guide. Tetrahedron: Asymmetry, 2008, 19, 519-536.

[10] Fogassy, E.; Faigl, F.; Soós, R.; Rákóczi, J. Process for the preparation of isomeric cyclopropanecarboxylic acids. U.S. Patent 4,599,444, July 8, 1986.

[11] Fogassy, E.; Faigl, F.; Ács, M.; Simon, K.; Kozsda, É.; Podanyi, B.; Czugler, M.; Reck, G. Structural studies on optical resolution via diastereomeric salt formation. Enantiomer separation for cis-permethrinic acid [cis-2,2-dimethyl-3-(2,2-dichlorovinyl)cyclopropanecarboxylic acid]. J. Chem. Soc., Perkin Trans. 2, 1988, 1385-1392.

[12] Simon, K.; Kozsda, É.; Böcskei, Zs.; Faigl, F.; Fogassy, E.; Reck, G. Structural studies on optical resolution via diasteroisomeric salt formation. Part 2. The conformational flexibility of $(S)-2$ benzylaminobutan-1-ol in enantiomer separation for permethrinic acids. J. Chem. Soc., Perkin Trans. 2, 1990, 1395-1400.

[13] Simándi, B.; Keszei, S.; Fogassy, E.; Kemény, S.; Sawinsky, J. Separation of enantiomers by supercritical fluid extraction. J. Supercrit. Fluids, 1998, 13, 331-336.

[14] Varga, D.; Bánsághi, Gy.; Martínez Pérez, J.A.; Miskolczi, S.; Hegedüs, L.; Simándi, B.; Székely, E. Chiral resolution of racemic cyclopropanecarboxylic acids in supercritical carbon dioxide. Chem. Eng. Technol., 2014, 37, 1885-1890.

[15] Freifelder, M.; Moore, M.B.; Vernsten, M.R.; Stone, G.R. Local anesthetics. VII. Monoalkylamino-4-alkoxy-3-aminobenzoates and 3-alkoxy-4-aminobenzoates. J. Am. Chem. Soc., 1958, 80, 43204323.

[16] Aitken, R.A.; Armstrong, D.P.; Galt, R.H.B.; Mesher, S.T.E. Synthesis and pyrolytic behaviour of thiazolidin-2-one 1,1-dioxides. $J$. Chem. Soc., Perkin Trans. 1, 1997, 2139-2145.

[17] Loosen, P.; Breviglieri, G.; Giagomo, B.; Contrini, S.; Assanelli, C. Process for the resolution of 6-methoxy-alpha-methyl-2naphthaleneacetic racemic acid into its enantiomers. U.S. Patent 5,760,287, June 2, 1998

[18] Xing, L.; Cheng, Ch.; Zhu, R.; Zhang, B.; Wang, X.; Hu, Y. Selfmodulated highly chemoselective direct-reductive-amination (DRA) of benzaldehydes straightforward to $\mathrm{N}$-monosubstituted benzylamine hydrochlorides. Tetrahedron, 2008, 64, 11783-11788.
[19] Tungler, A.; Ács, M.; Máthé, T.; Fogassy, E.; Bende, Z.; Petró, J. Effect of the conditions in heterogeneous catalytic hydrogenation on asymmetric induction. Appl. Catal., 1985, 17, 127-140.

[20] Jegham, S.; Das, B.C. A new route to optically pure cis- and trans2,5-disubstituted pyrrolidines. Tetrahedron Lett., 1989, 30, 28012804.

[21] Kumar, G.B.; Shah, A.C. Derivatives of $(R)$ - and (S)-2-amino-1butanol as possible anti-arrhythmics. Indian J. Chem., Sect. B, 1996, 35, 79-82.

[22] Bräuner-Osborne, H.; Bunch, L.; Chopin, N.; Couty, F.; Evano, G.; Jensen, A.A.; Kusk, M.; Nielsen, B.; Rabasso, N. Azetidinic amino acids: Stereocontrolled synthesis and pharmacological characterization as ligands for glutamate receptors and transporters. Org. Biomol. Chem., 2005, 3, 3926-3936.

[23] Medina, J.R.; Becker, C.J.; Blackledge, C.W.; Duquenne, C.; Feng, Y.; Grant, S.W.; Heerding, D.; Li, W.H.; Miller, W.H.; Romeril, S.P.; Scherzer, D.; Shu, A.; Bobko, M.A.; Chadderton, A.R.; Dumble, M.; Gardiner, C.M.; Gilbert, S.; Liu, Q.; Rabindran, S.K.; Sudakin, V.; Xiang, H.; Brady, P.G.; Campobasso, N.; Ward, P.; Axten, J.M. Structure-based design of potent and selective 3phosphoinositide-dependent kinase-1 (PDK1) inhibitors. J. Med. Chem., 2011, 54, 1871-1895.

[24] Deniz, P.; Turgut, Y.; Togrul, M.; Hosgoren, H. Pyridine containing chiral macrocycles: Synthesis and their enantiomeric recognition for amino acid derivatives. Tetrahedron, 2011, 67, 62276232.

[25] Leskovsek, V.; Urleb, U. A new approach to the synthesis of $\mathrm{N}$ aralkyl aminoalcohols. Synth. Commun., 1994, 24, 1415-1424.

[26] Stanton Pierce, J.; Salsbury, J.M.; Haden, W.W.; Willis, L.H. Local anesthetics. II. Alkoxybenzoates of 2-monoalkylamino-2-methyl-1propanols and 2-monoalkylamino-l-butanols. J. Am. Chem. Soc., 1942, 64, 2884-2885.

[27] Brown, E.; Penfornis, A.; Bayma, J.; Touet, J. Asymmetric reductions of ketones using lithium aluminium hydride modified with $N, N$-dialkyl derivatives of $(R)$-2-aminobutan-1-ol. Tetrahedron: Asymmetry, 1991, 2, 339-342.

[28] Asrof Ali, Sk.; Azhar Hashmi, S.M.; Siddiqui, M.N.; Mohammed I. M. Wazeer, M.I.M. Regiochemistry of mercury(II) oxide oxidation of unsymmetrical $\mathrm{N}, \mathrm{N}$-disubstituted hydroxylamines. Tetrahedron, 1996, 52, 14917-14928.

[29] Ueda, S.; Terauchi, H.; Yano, A.; Ido, M.; Matsumoto, M.; Kawasaki, M. 4,5-Disubstituted-1,3-oxazolidin-2-imine derivatives: A new class of orally bioavailable nitric oxide synthase inhibitor. Bioorg. Med. Chem. Lett., 2004, 14, 313-316.

[30] Togrul, M.; Askin, M.; Hosgoren, H. Synthesis of chiral monoaza15-crown-5 ethers from a chiral amino alcohol and enantiomeric recognition of potassium and sodium salts of amino acids. Tetrahedron: Asymmetry, 2005, 16, 2771-2777.

[31] Largeron, M.; Fleury, M.-B. A biomimetic electrocatalytic system for the atom-economical chemoselective synthesis of secondary amines. Org. Lett., 2009, 11, 883-886.

[32] Schiff, H. Eine neue Reihe organischer Basen, Justus Liebigs Ann. Chem., 1864, 131, 118-119.

[33] Pawlenko, S. In: Methoden der organischen Chemie (HoubenWeyl); Klamann, D.; Hagemann, H., Eds.; Georg Thieme Verlag: Stuttgart, New York, 1990; Vol. E14b, Part 1, pp. 222-281.

[34] Singh, B. Synthesis of ethambutol. U.S. Patent 3,944,618, March 16, 1976.

[35] Baltzly, R.; Russell, P.B. Catalytic debenzylation. III. The influence of $\alpha$-substitution on the ease of hydrogenolysis. $J$. Am. Chem. Soc., 1953, 75, 5598-5602.

[36] Rylander, P.N. In: Catalysis in Organic Syntheses; Jones W.H., Ed.; Academic Press, New York, 1980; pp. 155-171.

[37] Máthé, T.; Tungler, A.; Petró, J. Process for the preparation of supported metal catalysts. U.S. Patent 4,361,500, November 30, 1982.

[38] Sárkány, A. Personal communication.

[39] NIST Chemistry WebBook, NIST Standard Reference Database Number 69; Linstrom, P.J.; Mallard, W.G., Eds.; National Institute of Standards and Technology, Gaithersburg MD, 20899; http://webbook.nist.gov/chemistry [Accessed Nov 24, 2014]. 